\title{
Study on Training Mode for Skill-oriented and Application-oriented Translation Talents under University-Enterprise Cooperation
}

\author{
Xue Lv \\ Wuhan Donghu University, Wuhan Hubei, 430212, China
}

Key words: University-enterprise cooperation, Skill-oriented, Application-oriented, Translation talent training mode.

\begin{abstract}
In national internationalization development, the demand for translation talents increases gradually. Hence, colleges need to formulate sound translation talent training scheme to improve the work quality. However, some colleges cannot well train skill-oriented and application-oriented talents under the mode of university-enterprise cooperation, and it is hard to meet national demand for talents. Thus, colleges must formulate sound translation talent training mode under university-enterprise cooperation to cultivate skill-oriented and application-oriented talents.
\end{abstract}

\section{Introduction}

When formulating the teaching mode based on university-industry cooperation, colleges must pay attention to training translation talents, guarantee to cultivate skill-oriented and application-oriented talents, improve the application efficiency of talent training mode, meet China's demand for translation talents and promote national modernization development.

\section{Application situation of university-industry cooperation teaching mode}

Although some colleges have established sound university-enterprise cooperation mode, some problems which are difficult to solve still exist in practical application. Thus, the work quality cannot improve, and the expected management goal cannot be achieved. These are reflected in the following points:

Firstly, theoretical exploration of university-enterprise cooperation. In the practical development process of colleges in China, university-enterprise cooperation teaching mode is still in the stage of exploration and practice. In 2016, some colleges enhanced talent training force in educational system reform, overall reformed talent training mode, improved talent training quality and enhanced the training force for skill-oriented and application-oriented talents to make sure talent training accord with relevant requirements. However, when applying university-enterprise cooperation mode, some colleges still cannot overall cultivate students' employability, expand students' employment channels and improve work quality in the ways of practice and communication. In order to adapt to the development demand of China's education, some colleges start to refer to other successful modes to explore new talent training cooperation mode, which is difficult to rationally allocate talent training mode.

Secondly, translation talent training defects. Although some colleges have formulated diversified enrollment modes and training schemes during training translation talents, some problems still exist for teaching capacity and practical teaching system. The quality of translation talent training work cannot improve, and talent training system cannot be optimized. Even the application quality of college talent training scheme is threatened. Meanwhile, some colleges cannot utilize diversified cooperation modes to cooperate with other enterprises in translation talent training process. It is hard 
for some colleges to deeply develop university-enterprise cooperation mode. Students' skill and application ability training is even affected.

Thirdly, many traditional talent training modes are contained in university-enterprise cooperation mode. During cultivating translation talents, some colleges fail to realize the importance of university-enterprise cooperation and still apply traditional training scheme. So, it is hard to enhance talent training effect, and university-enterprise cooperation teaching quality is even affected. Besides, some colleges can neither establish thorough management system according to talent development needs nor give play to the function of university-enterprise cooperation teaching mode. As well, it is difficult to motivate talents' learning interest.

Fourthly, there is short of sound talent training scheme. When applying university-enterprise cooperation teaching mode, colleges cannot make sound talent training scheme, and it is difficult for them to apply various talent training systems to carry out skill-oriented and application-oriented talent training activity, which results in the reduction of work quality. Moreover, some colleges cannot form good cooperation mode with enterprises during training translation talents, and they are difficult to create more profits for enterprises. Thus, enterprises are not active enough for university-enterprise cooperation. Some enterprises even refuse university-enterprise cooperation.

Fifthly, there is lack of high-quality teaching team. During training translation talents, colleges in China do not build a high-quality teaching team and cannot carry out relevant activities with active teaching methods, thus leading to low teaching quality. Some colleges take no count of teachers' professional quality and employ some teachers without work experience. Thus, teachers cannot rationally adjust the relationship between enterprises and students in university-enterprise cooperation, and it is hard to give full play to the function of university-enterprise cooperation teaching mode. In addition, during employing teachers, human resource management department of a college cannot implement periodical training about professional knowledge and advanced skills. Hence, it is difficult to enhance teachers' teaching ability. Meanwhile, human resource management department can neither carry out training about the knowledge of ideology and politics nor train teachers' professional ethics. Thus, it is hard to exert the positive function of university-enterprise cooperation mode. All these affect the development of college talent training work.

Sixthly, colleges lack sound teaching management system for translation major. There is no sound management system for translation talent training. Colleges cannot carry out relevant work according to teaching requirements and characteristics of translation major, and it is hard to improve the quality of translation talent training work. At the same time, if there is short of sound management system in practical teaching, teachers' behaviors cannot be restrained, and it is also difficult to specify the teaching objective.

\section{Measures for skill-oriented and application-oriented talent training under university-enterprise cooperation}

During training translation talents, colleges must attach importance to the application of university-enterprise cooperation mode, improve talent training quality, optimize skill-oriented and application-oriented talent training system, give play to the function of university-enterprise cooperation teaching mode, reduce the problems and improve talent training quality. The detailed measures are as follows:

\section{To build practice bases}

During training translation talents, college teachers must pay attention to practice. Special translation practice bases should be built. Besides, the cooperation among the government, enterprises and colleges should be facilitated to improve talent training quality. Firstly, enterprises must enhance practice base building, take active part in college talent training activity and offer the base for students to learn translation knowledge. Secondly, colleges need to attach importance to the cooperation with enterprises, guarantee to form formal cooperation form with enterprises, sign the cooperation agreement, enhance the effect of university-enterprise cooperation and strengthen the 
effect of practice base building work. Finally, the government sector should strongly support the application of university-enterprise cooperation mode, back up the cooperation between enterprises and colleges, utilize preferential policies to motivate enterprises' cooperation enthusiasm, improve the application quality of university-enterprise cooperation mode and provide practice bases for translation talent training ${ }^{[1]}$.

\section{To train talents jointly by colleges and enterprises}

When colleges apply university-enterprise cooperation mode, they need to cultivate translation talents together with enterprises and formulate sound skill-oriented and application-oriented talent training system. At present, the disconnection between practical teaching and theory teaching appears in university-enterprise cooperation mode, which seriously affects long-term development of enterprises. Thus, colleges and enterprises must formulate sound cooperation teaching mode to cultivate skill-oriented and application-oriented talents together. On the one hand, when students learn skill-oriented knowledge in enterprises, they may know enterprise atmosphere and talent demand features according to enterprises' actual needs, which can enhance students' professional skill mastery effect. On the other hand, colleges guide students to grasp translation skills and solve their employment problem ${ }^{[2]}$.

\section{To set up university-enterprise talent training course}

After colleges cooperate with enterprises, they must set up talent training course and guarantee to carry out relevant work in accordance with translation talent training requirements and features, without the influence on the development of talent training work. Firstly, during setting up translation courses, colleges and enterprises should jointly analyze international requirements for translation talents, confirm the talent training objective and guarantee to improve talent training quality. Secondly, during training translation talents, colleges and enterprises need to continuously adjust the contents of practice and theory courses, formulate sound teaching scheme and add CAT teaching so that students can master all kinds of translation skills and improve teaching quality. Finally, colleges and enterprises should focus on students' performance in practical activities, discover the problems existing in translation skill application in time and take effective actions to improve talent training scheme and improve talent training quality ${ }^{[3]}$.

\section{To establish international practice platform for university-enterprise cooperation}

After colleges cooperate with enterprises, international practical teaching platform must be established to guide students to accumulate more practical experience. Colleges may utilize off-campus practice mode to offer the way for students to get credits and motivate their practice participation interest. For example, colleges may cooperate with the sponsor of international fair and require students to participate in translation activity to cultivate their translation skills and application ability. Meanwhile, college translation teachers may cooperate with high-quality employees of enterprises and offer the platform for students to practice translation ability, which can cultivate students' language expression ability and sociability, establish self-confidence, enhance their employment awareness and improve translation talent training quality, except enhancing their translation skills.

\section{To increase high-quality teaching team}

When colleges and enterprises cooperate to train translation talents, colleges and enterprises need to attach importance to talent team building, train double-capability and coach-type teachers and make them guide students to learn translation skills in teaching. Firstly, translation talent training should serve as the core system, and teachers' sociality and stability training purpose should be specified. Besides, effective measures should be adopted to train teaching team. Secondly, it is required to make sure teachers can cultivate students' independent learning ability in teaching, own rich connotations, overall grasp practical teaching knowledge, form certain teaching ability and enhance the teaching effect. Finally, colleges and enterprises may employ some translation experts to guide students' 
learning, or offer the opportunity of advanced studies for teachers to improve teachers' teaching ability $^{[4]}$.

\section{To establish competition events by colleges and enterprises}

Under university-enterprise cooperation teaching mode, colleges must set up the competition platform for students so that students can actively participate in the competition and gradually improve their translation ability. Firstly, colleges and enterprises may set the interpretation competition scheme according to students' actual needs. The competition contents should not be repeated and should be innovative. For example, the enterprise may simulate the scene of receiving foreign guests in routine work and guide students to participate in the simulation competition. The college may carry out UN conference interpreting competition. During setting the competition scheme, the interestingness of competition process must be guaranteed to motivate students' participation interest. Secondly, both the college and the enterprise should invite professional interpreters or foreign affairs agency under the government agency as the judges for the competition to evaluate students' interpretation ability from professional perspective, which can improve competition fairness and make students discover their problems in time and adopt effective measures to solve them. Finally, in the interpretation competition process, certain practice opportunities should be created for students to improve their interpretation ability and optimize university-enterprise cooperation teaching mode ${ }^{[5]}$.

\section{Thought on university-enterprise cooperation teaching}

Colleges must summarize the experience of university-enterprise cooperation teaching, find the problems in time and take effective actions to solve them. Currently, the following problems still exist in university-enterprise cooperation teaching. Firstly, students lack enthusiasm for enterprise practice activity, which cannot improve the effect of experiential learning. Meanwhile, some students fail to reach enterprises' requirements for translation talents after university-enterprise cooperation learning, so they cannot work for the enterprises. Secondly, some enterprises think little of students' experiential learning and cannot train students' translation skills according to requirements of colleges. Thus, it is hard to improve the application effect of university-enterprise cooperation teaching mode. Therefore, colleges must do the following during university-enterprise cooperation:

Firstly, before cooperation with enterprises, colleges need to sign normative management document through negotiations. On the one hand, students are required to abide by various principles of enterprises in the practice period, without violation of rules. On the other hand, enterprises must attach importance to training students' practical ability and reach the expected cooperation purpose when training students.

Secondly, colleges should sign the valid agreement document with enterprises. After the document is signed, long-term cooperation relationship will be established to jointly build off-campus practice bases so as to train translation talents for the state.

Thirdly, it is required to pay attention to cooperation with famous translation institutions and translation companies. During university-enterprise cooperation, Chinese colleges ignore the fame of practice bases and cannot offer the practice platform with long-term development ability for students. It is hard to guide students to master more social knowledge. Thus, colleges should attach importance to cooperation with famous translation institutions and translation companies and create professional practice bases for students. On the one hand, professional quality and translation ability of instructors in such institutions or companies are high, and they may utilize rich work experience to train translation talents and improve training quality. On the other hand, students can learn more skills and knowledge from translation practice, sum up some social experience and form correct cognition of translation work. Moreover, this also contributes to making sound employment planning scheme and improving learning quality. 


\section{Conclusions}

Under university-enterprise cooperation mode, colleges and enterprises should focus on translation talent training work. Before the cooperation, they should sign relevant documents to make sure students can learn more translation knowledge in the enterprises. Besides, colleges should pay attention to students' mastery of applied knowledge, train students' translation skills, select multiple enterprises for cooperation and make sure students sum up experience in repeated practice and grasp more translation knowledge.

\section{References}

[1] Sun Wenyuan, Dai Congteng, Study on Skill-oriented and Application-oriented Translation Talent Training Mode under University-Enterprise Cooperation, Shanghai Journal of Translators, 2016(3):72-76.

[2] Liu Hongwei, Exploration of Training Professional Translation Talents under University-Enterprise Cooperation - Case Study of “Changsha-Zhuzhou-Xiangtan” Region, Journal of Huaihua University, 2013(7):111-113.

[3] Feng Xiaolei, Translation Talent Training under University-Enterprise Cooperation, Theoretic Observation, 2016(9):121-122.

[4] Wu Hanzhou, On Cultivating Practical Translators under Order-typed Education -Taking Beibu Gulf Economic Zone as Example, Higher Education Forum, 2014(2):45-48.

[5] Liang Fali, Exploration on University-Enterprise Cooperation Mode for Translation Major in Huarui College, Journal of Heilongjiang Vocational Institute of Ecological Engineering, 2016,29(3):107-108. 